\title{
The functional sequelae of schizophrenia: consequences of long-term pharmacotherapy and the neurobiology of addiction
}

\author{
P. Falkai • H.-J. Möller
}

Published online: 17 February 2011

(C) The Author(s) 2011. This article is published with open access at Springerlink.com

This issue contains different aspects of the broad spectrum of clinical psychiatry.

In the paper by Schaub et al. [1], the interplay between psychopathological syndromes and psychosocial functioning in chronic schizophrenia is examined. This is of special importance facing a continuous discussion what our treatment options mean to real life functioning for the patients. On the other hand, it is important to analyse whether psychopathological abnormalities revealed in patients are as important for the patients as to the examiner.

Suffering from schizophrenia means to a substantial proportion of the patients to take antipsychotic agents for a significant proportion of their lifetime, leading to side effects like the metabolic syndrome. Therefore, it is important to have reliable data on the prevalence and clinical correlates of it in patients suffering from schizophrenia as documented by Barbosa et al. [2]. However, not only patients with schizophrenia suffer from the metabolic consequences of long-term pharmacotherapy but also patients with acute depression face similar problems as was outlined by Richter et al. [3]. Along these lines, it should be stressed that the pharmacogenetics of antidepressant treatment will in the near future not only give support in the choice of the right substance looking at the efficacy but furthermore taking the special side effect profile into account [4]. Along these lines, the paper by Illi et al. [5]

P. Falkai ( $\square)$

Department of Psychiatry and Psychotherapy,

University of Göttingen, Von-Siebold-Str. 5,

37075 Göttingen, Germany

e-mail: pfalkai@gwdg.de

H.-J. Möller

Psychiatry Hospital, Ludwigs-Maximilians-University Munich,

Nussbaumstr. 7, 80336, Munich, Germany analyses the connection between 5-HTTLPR and selective serotonin reuptake inhibitors in major depression. Finally concluding this complex, the interest is drawn to a paper by Kikuchi et al. [6] performing an internet survey on patients' attitude towards side effects of antidepressant treatment.

Linking state-of-the-art electrophysiology with personality traits, Mittermeier et al. [7] examined the role of auditory-evoked potentials in an emotional choice reaction task in relation to personality traits measured by the NEO FFI.

Researching the proteome in major psychiatric illnesses beyond schizophrenia or depression (as laid out in [8]), a recent study analysing the human amygdala found an impact of tubulin on drug-abusing behaviour [9]. In an article in this issue examining the consequences of alcohol abuse, Wedekind et al. [10] analysed S100B and homocysteine in the acute alcohol withdrawal syndrome. These and other neurobiological findings seem to define subgroups of patients with addictive behaviour pointing to the necessity of individualised treatments in alcohol dependents [11].

Open Access This article is distributed under the terms of the Creative Commons Attribution Noncommercial License which permits any noncommercial use, distribution, and reproduction in any medium, provided the original author(s) and source are credited.

\section{References}

1. Schaub D, Brüne M, Jaspen E, Pajonk FG, Bierhoff HW, Juckel G (2010) The illness and everyday living: close interplay of psychopathological syndromes and psychosocial functioning in chronic schizophrenia. Eur Arch Psychiatry Clin Neurosci. doi: 10.1007/s00406-010-0122-1

2. Barbosa IG, Huguet RB, Mendonça VA, Sousa LP, Neves FS, Bauer ME, Teixeira AL (2010) Increased plasma levels of soluble TNF receptor I in patients with bipolar disorder. Eur Arch Psychiatry Clin Neurosci. doi:10.1007/s00406-010-0116-z 
3. Richter N, Juckel G, Assion HJ (2010) Metabolic syndrome: a follow-up study of acute depressive inpatients. Eur Arch Psychiatry Clin Neurosci 260:41-49

4. Zobel A, Maier W (2010) Pharmacogenetics of antidepressive treatment. Eur Arch Psychiatry Clin Neurosci 260:407-417

5. Illi A, Poutanen O, Setälä-Soikkeli E, Kampman O, Viikki M, Huhtala H, Mononen N, Haraldsson S, Koivisto PA, Leinonen E, Lehtimäki $\mathrm{T}$ (2010) Is 5-HTTLPR linked to the response of selective serotonin reuptake inhibitors in MDD? Eur Arch Psychiatry Clin Neurosci. doi:10.1007/s00406-010-0126-x

6. Kikuchi T, Uchida H, Suzuki T, Watanabe K, Kashima H (2010) Patients' attitudes toward side effects of antidepressants: an Internet survey. Eur Arch Psychiatry Clin Neurosci. doi:10.1007/ s00406-010-0124-z

7. Mittermeier V, Leicht G, Karch S, Hegerl U, Möller HJ, Pogarell O, Mulert C (2010) Attention to emotion: auditory-evoked potentials in an emotional choice reaction task and personality traits as assessed by the NEO FFI. Eur Arch Psychiatry Clin Neurosci. doi:10.1007/s00406-010-0127-9

8. Martins-de-Souza D, Harris LW, Guest PC, Turck CW, Bahn S (2010) The role of proteomics in depression research. Eur Arch Psychiatry Clin Neurosci 260:499-506

9. Zill P, Vielsmeier V, Büttner A, Eisenmenger W, Siedler F, Scheffer B, Möller HJ, Bondy B (2010) Postmortem proteomic analysis in human amygdala of drug addicts: possible impact of tubulin on drug-abusing behavior. Eur Arch Psychiatry Clin Neurosci. doi:10.1007/s00406-010-0129-7

10. Wedekind D, Neumann K, Falkai P, Malchow B, Engel KR, Jamrozinski K, Havemann-Reinecke U (2010) S100B and homocysteine in the acute alcohol withdrawal syndrome. Eur Arch Psychiatry Clin Neurosci. doi:10.1007/s00406-010-0121-2

11. Mann K, Hermann D (2010) Individualised treatment in alcoholdependent patients. Eur Arch Psychiatry Clin Neurosci 260(Suppl 2): $116-120$ 